UDC 615.454.2:618.15-002:616-08

O. V. Dolzhykova, L. N. Maloshtan

National University of Pharmacy

\title{
MICROBIOLOGICAL PREDICATION OF VAGINAL SUPPOSITORIES “MELANIZOL” USING FOR NONSPECIFIC VAGINITIS TREATMENT
}

The article considers the vaginal suppositories "Melanizol" based on metronidazole, and tea tree oil influence on the museum and clinical microorganisms strains, that may be potential agents of vaginal infections. Established antimicrobial activity of vaginal suppositories "Melanizol" against the following strains of micro-organisms Staphylococcus aureus, Basillus subtilis, Klebsiella, and Escherichia coli, and also found their antifungal activity against Candida albicans.

Key words: antibacterial activity; vaginal suppositories; tea tree oil; metronidazole

\section{INTRODUCTION}

Non-specific (aerobic) vaginitis are arising from changes in normal vaginal microflora, causing signs of inflammation. The cause of vaginitis is mainly aerobic microorganisms microorganisms from intestinal commensals or other aerobic pathogenic aerobic bacteria (Escherichia, Enterococci, Streptococci, Staphylococci etc.). Clinical symptoms depend on the type and intensity, and have a high tendency to relapse and chronic leaks. Inflammation and ulcers in the non-specific (aerobic) vaginitis may increase the risk of infections, sexually transmitted infections [10].

The causes of recurrent infections of the genitourinary system in women are similar, including in healthy women with normal structure of the genitourinary system. According to statistics, $30 \%$ to $44 \%$ of women have infections relapse within six months. Relapses tend to cause the same kinds of pathogens that caused previous infection. Risk factors include: In premenopausal women, sexual intercourse three or more times per week, spermicide use, new or multiple sex partners. In postmenopausal women, risk is primarily increased by sequelae of lower estrogen levels. Patient-initiated treatment lowers the cost of diagnosis, number of physician visits, and number of symptomatic days compared with physician-initiated treatment. It also reduces antibiotic exposure compared with antibiotic prophylaxis. Antibiotic prophylaxis effectively limits the recurrence of urinary tract infection but increases the risk of antibiotic resistance and adverse effects [8].

Over the past decade streptococci lost their original meaning in the etiology of vaginitis. This is due to their lack of resistance to antibiotics. Staphylococci unlike strepto-

(c) Dolzhykova O. V., Maloshtan L. N., 2016 cocci have the ability to form antibiotic-resistant strains that have high virulence, which contributes to their leading role in the etiology of inflammation of the female genital organs for a long time. But under the influence of antibiotics II and III generation in the first place were anaerobic gram-negative (Escherichia coli, Proteus vulgaris, Enterobacteria, Klebsiella and others). Increasingly began to meet microbial associations, causing severe course of inefficiency non-specific (aerobic) vaginitis and its treatment. According to the literature Escherichia coli is present in allocations of 80-85\% women, Klebsiella and Proteus - 10-20\%, group B Streptococci, Enterococci and Staphylococci - $5 \%$. Microorganisms are involved in the inflammatory process are excessive dangerous by reason of activation of inflammatory mediators $[3,7]$.

Metronidazole and its analogues are one of the commonly used drugs for treatment of non-specific vaginitis [7]. The drug is active for Trichomonas vaginalis, Gardnerella vaginalis, Giardia intestinalis, Entamoeba histolytica, obligate anaerobic bacteria: Bacteroides spp., Fusobacterium spp., Veillonela spp.; some gram-positive bacteria : Eubacterium spp., Clostridium spp., Peptococcus spp., Peptostreptococcus spp., and Helicobacter pylori.

Due to polyetiologic of non-specific vaginitis can be weighed both anaerobic and aerobic microorganisms and candida infection complicated, and requires a comprehensive approach to treatment. As such means tea tree oil can be recommended for using, which is very interesting materials for pharmaceutical use [1], contains over one hundred terms and their spirits from which terpinen-4-ol, $\alpha$-pinene, linalool and $\alpha$-terpineol considered essential components of the antimicrobial activity and fungicidal activity. Streptococcus mutans and Prevotela intermedia were sensitive to tea tree oil [5], and tea tree oil has bactericidal effect on Bacillus cereus, Corynebacterium sp., Entero- 
coccus faecalis, Escherichia coli, Fusobacterium nucleatum, Klebsiella pneumonia, Micrococcus luteus, Peptostreptococcus anaerobius, Prevotella spp., Prevotella intermedia, Proteus vulgaris, Pseudomonas aeruginosa, Staphylococcus aureus, Staphylococcus aureus (methicillin resistant), Staphylococcus epidermidis, Staphylococcus hominis, Streptococcus pyogenes [9].

On the base of National University of Pharmacy of TL department by staff under the supervision T. H. Yarnykh new vaginal suppositories "Melanizol" developed [4], suppositories contain compositions: metronidazole, tea tree oil and base (polyethylene oxide, PEO-1500: PEO-400) are promising for the treatment of nonspecific vaginitis and bacterial vaginosis.

The aim of our study was to investigate the antibacterial properties of new vaginal suppositories "Melanizol” to museum test-strains and clinical strains.

\section{MATERIALS AND METHODS}

According to the order of Ukraine Ministry of Health No. 167 of 05.04 .2007 . "On confirmation of guidance" Determination of the sensitivity of microorganisms to antibiotics [6] based on laboratory culture media for microorganisms Institute of Microbiology and Immunology them. I. I. Mechnikov led by Ph. D., senior researcher T. P. Osolodchenko. Study of antibacterial activity of vaginal suppositories "Melanizol" drug-comparison suppositories "Hravahin" and tea tree oil was carried out by agar diffusion in modifying wells [2].

Study of antibacterial activity of vaginal suppositories "Melanizol" drug-comparison suppositories "Hravahin" and tea tree oil was carried out by agar diffusion in modifying wells Staphylococcus aureus ATCC 26923, Escherichia coli ATCC 25922, Pseudomonas aeruginosa ATCC 27853, Basillus subtilis ATCC 6633, Candida albicans ATCC 885653. Microbial load was 10 microbial cells per $1 \mathrm{ml}$ of medium and establishes by McFarland standard. 18-24 hour culture of microorganisms was used in the work. For re- search we used agar Mueller-Hinton. Also the antimicrobial properties investigated on the clinical strains Staphylococcus aureus 576, 24 and 421, Enterococcus faecalis 17, Escherichia coli 25, Klebsilla pneumoniae 34, Enterobacter aerogenes 45, Candida albicans 65 and 46.

We determined the reactivity of antibiotics on two layers of dense nutrient medium, poured into Petri dishes. Evaluation of antimicrobial activity carried out by the diameter of the zone delayed the growth of microorganisms. Differentiation susceptible, moderately resistant strains was performed according to the recommendations of the National Committee for clinical laboratory standards (NCCLS, USA). During the evaluation of new antimicrobial agents and strains against antibiotics in the study used the following criteria: no delays microbial growth zones around wells and delay zones of $10 \mathrm{~mm}$ indicate that the organism is not sensitive to the hole made by the drug or antibiotic concentration; stunted growth zone diameter of 10-15 mm indicate low sensitivity to the cultures studied concentrations of antibiotic substances; stunted growth zone diameter of $15-25 \mathrm{~mm}$ are measured as an indicator of the sensitivity of the microorganism to the IMP; stunted growth zone whose diameter exceeds $25 \mathrm{~mm}$, indicate a high sensitivity of microorganisms to studied agents.

Statistical analysis of experimental data was performed by conventional methods with statistical software Microsoft Excel 2007 and Statistic 6.0.

\section{RESULTS AND DISCUSSION}

The level of antimicrobial activity of experimental samples evaluated in diameter zone stunted growth of microorganisms. The experimental results are presented in Fig. 1.

According to the results of microbiological studies (Fig. 1), suppositories, vaginal "Melanizol" exhibit activity against strains Basillus subtilis level comparator suppositories "Hravahin" and significantly surpass it in terms

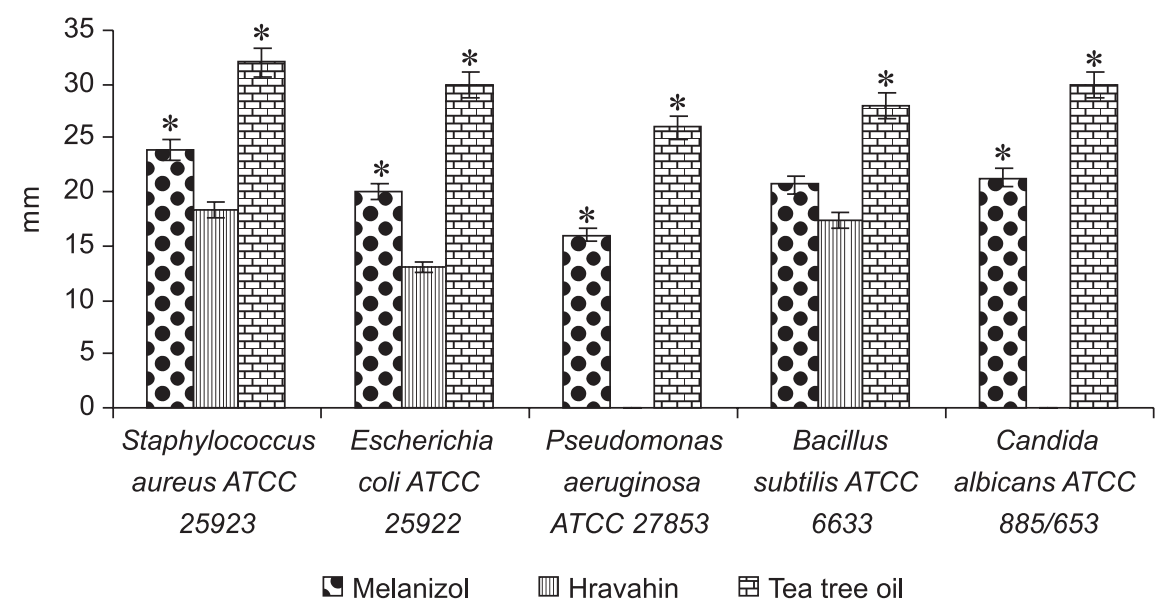

Fig. 1. Comparative evaluation of antimicrobial activity of vaginal suppositories "Melanizol", suppositories "Hravahin" and tea tree oil

Note: * - significantly relative to comparator suppositories "Hravahin". 


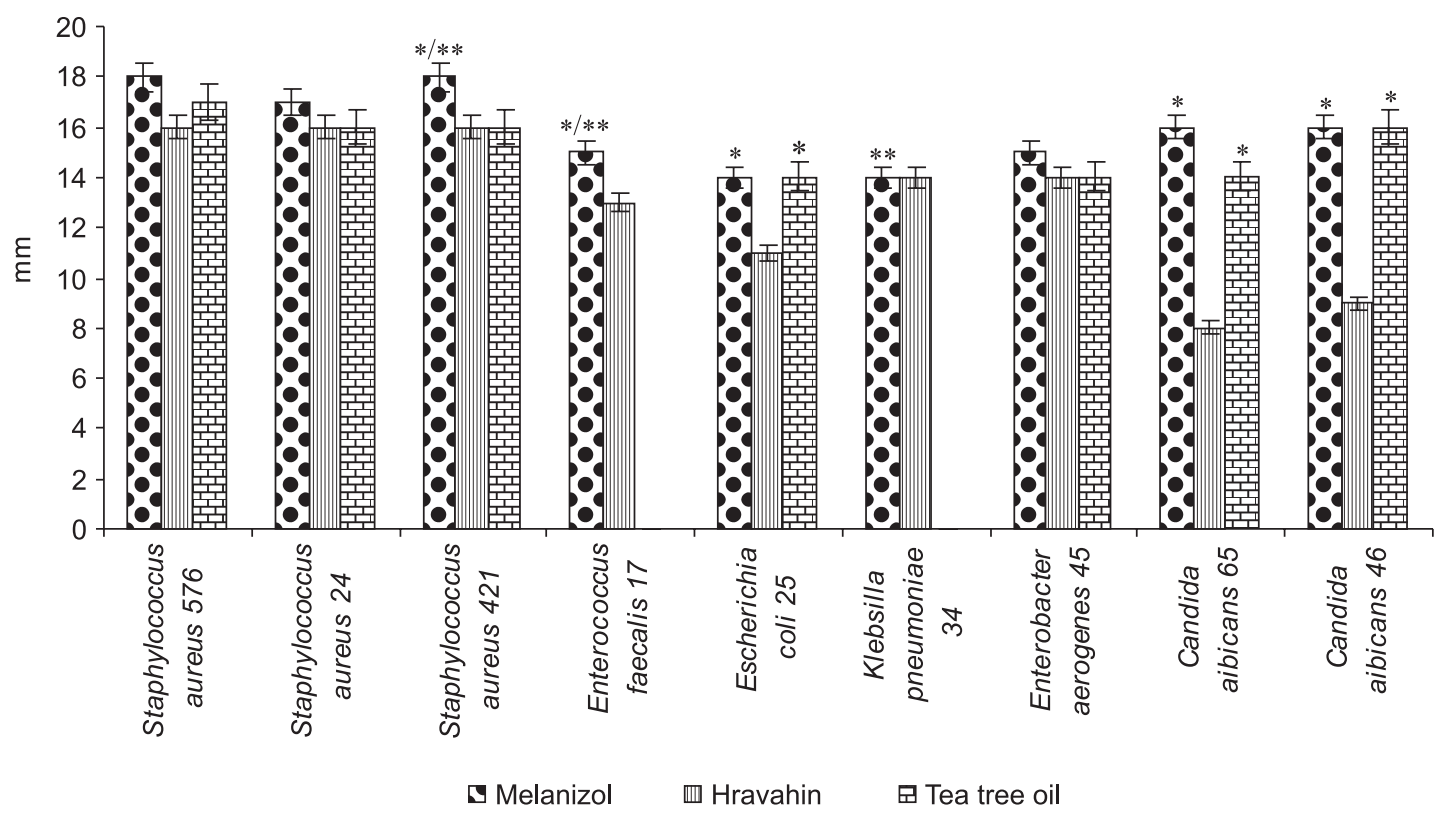

Fig. 2. Antibacterial properties vaginal suppositories "Melanizol", suppositories "Hravahin" and tea tree oil in relation to the clinical strains

Note: * significantly relative to comparator suppositories "Hravahin"; ** - significantly in relation to tea tree oil.

of activity, inhibiting the growth of Staphylococcus aureus, Pseudomonas aeruginosa, and as Escherichia coli and Candida albicans, which activity caused by the presence of vaginal suppositories of tea tree oil, which suppositories "Melanizol" inferior to its activity.

Given the preliminary results of microbiological testing in relation to the museum strains, it would conduct additional study of the effect of vaginal suppositories "Melanizol" and comparing drug suppositories "Hravahin" in clinical strains of bacteria. The data are presented in Fig. 2.

Data obtained from studies (Fig. 2) show that the suppositories vaginal "Melanizol" exhibit antibacterial activity against clinical strains of Staphylococcus aureus, Enterococcus faecalis, Escherichia coli, Klebsilla pneumoniae and Candida aibicans, significantly outperforming the comparator suppositories "Hravahin" and not yielding tea tree oil, and their effect on Enterococcus faecalis, Klebsilla pneumoniae significantly surpassing it.

Thus, based on the findings, we can conclude that vaginal suppositories "Melanizol" exhibit antimicrobial activity against clinical strains of microorganisms which are, at present, the most common agents of vaginal infections.

\section{CONCLUSIONS}

1. Thus, vaginal suppositories "Melanizol" exhibit antimicrobial activity against strains museum Staphylococcus aureus, Pseudomonas aeruginosa, Escherichia coli and Candida albicans significantly outperforming the comparator suppositories "Hravahin".

2. Vaginal Suppositories "Melanizol" exhibit antibacterial activity against clinical strains of Staphylococcus aureus, Enterococcus faecalis, Escherichia coli, Klebsilla pneumoniae, which can be potential agents of vaginal infections, suppositories significantly exceeding "Hravahin" and not yielding tea tree oil.

3. Acting on museum and clinical strains of Candida albicans, vaginal suppositories "Melanizol" do antifungal effect.

4. Based on the above, we can conclude that vaginal suppositories "Melanizol" is a promising tool for further study as a drug for the treatment of bacterial vaginosis and nonspecific vaginitis burdened microbial flora.

\section{REFERENCES}

1. Азнабаева Л. М. Лекарственная регуляция антилизоцимной активности стафилококков [Электронный ресурс] / Л. М. Азнабаева, С. Б. Киргизова // Современные проблемы науки и образования. - 2013. - № 2 (46). - URL: www.science-education.ru/108-8719

2. Вивчення специфічної активності антимікробних лікарських засобів: [метод. рекоменд.] / За ред. Ю. Л. Волянського. - К., 2004. - 38 с.

3. Кира Е.Ф. Неспецифический вагинит и его влияние на репродуктивное здоровье женщины (обзор литературы) [Текст] / Е. Ф. Кира, С. З. Муслимова // Проблемы репродукции. - 2008. - № 5 . P. 8-14.

4. Пат. 96646 України на винахід, МПК (2011.01), А 61 К 9/02 , А 61 К 31/4164 , А 61 К 36/61, А 61 Р 15/00. Протизапальний засіб у формі песаріїв з метронідазолом і олією чайного дерева / Т. Г. Ярних, Ю. В. Левачкова, Л. М. Малоштан, К. О. Степанова; заявник та патентовласник Національний фармацевтичний університет. - № a 201001 
134. - Заявл.: 04.02.2010. Опубл.: 25.11.2011. Бюл. № 22.

5. Политун А. М. Новые гигиенические средства по уходу за полостью рта [Текст] / А. М. Политун, Е. А. Венгер // Эндодантист. - 2010. - № 2 (4). P. 1-4.

6. Про затвердження методичних вказівок «Визначення чутливості мікроорганізмів до антибактеріальних препаратів» [Електронний ресурс]: Наказ Міністерства охорони здоров'я України № 167 від 05.04.2007. - URL: http://mozdocs.kiev.ua/view. php?id=6958

7. Хамаганова И. В. Бактериальный вагиноз [Электронный ресурс] / И. В. Хамаганова // Лечащий врач. - 2008. - № 10/7. - URL: http://www.lvrach. $\mathrm{ru} / 2007 / 10 / 4716698$

8. Arnold J. J. Common Questions About Recurrent Urinary Tract Infections in Women [Text] / J. J. Arnold,
L. E. Hehn, D. A. Klein // Am. Fam. Physician. - 2016. Vol. 93 (7). - P. 560-569.

9. Carson C. F. Melaleuca alternifolia (Tea Tree) Oil: a Review of Antimicrobialand Other Medicinal Properties [Text] / C. F. Carson, K. A. Hammer, T. V. Riley // Clinical Microbiol. Rev. - 2006. - Vol. 19, № 1. - P. 50-62.

10. Dermendijev T. Epidemiological, clinical and microbiological findings in women with aerobic vaginitis [Text] / T. Dermendijev, B. Pehlivanov, K. Hadjieva, S. Stanev // Akush. Ginekol. (Sofiia). - 2015. Vol. 54 (9). - P. 4-8.

11. Petersen E. E. Infections in Obstetrics and Gynecology: textbook and atlas [Text] / E. E. Petersen. - New York: Thieme, 2006. - 260 p.

12. Romanik M. Aerobic vaginitis-diagnostic problems and treatment [Text] / M. Romanik, A. Wojciechowska-Wieja, G. Martirosian // Ginekol. Pol. - 2007. Vol. 78, № 6. - P. 488-491.

\section{УДК 615.454.2:618.15-002:616-08}

о. В. Должикова, Л. М. Малоштан

\section{МІКРОБІОЛОГІЧНЕ ОБГРУНТУВАННЯ ВИКОРИСТАННЯ СУПОЗИТОРІЇВ ВАГІНАЛЬНИХ «МЕЛАНІЗОЛ" ДЛЯ ЛІКУВАННЯ НЕСПЕЦИФІЧНИХ ВАГІНІТІВ}

Розглянуто вплив супозиторіїв вагінальних «Меланізол» на основі метронідазолу та олії чайного дерева на музейні та клінічні штами мікроорганізмів, які можуть бути потенційними збудниками вагінальних інфекцій. Встановлено антимікробну активність супозиторіїв вагінальних «Меланізол» по відношенню до наступних штамів мікроорганізмів Staphylococcus aureus, Basillus subtilis, Klebsiella та Escherichia coli, а також встановлено їх протигрибкову дію проти Candida albicans.

Ключові слова: антибактеріальна активність; супозиторії вагінальні; олія чайного дерева; метронідазол

\section{УДК 615.454.2:618.15-002:616-08 \\ Е. В. Должикова, Л. Н. Малоштан \\ МИКРОБИОЛОГИЧЕСКОЕ ОБОСНОВАНИЕ ИСПОЛЬЗОВАНИЯ СУППОЗИТОРИЕВ ВАГИНАЛЬНЫХ «МЕЛАНИЗОЛ" ДЛЯ ЛЕЧЕНИЯ НЕСПЕЦИФИЧЕСКИХ ВАГИНИТОВ}

Рассмотрено влияние суппозиториев вагинальных «Меланизол» на основе метронидазола и масла чайного дерева на музейные и клинические штаммы микроорганизмов, которые могут быть потенциальными возбудителями вагинальных инфекций. Установлено антимикробную активность суппозиториев вагинальных «Меланизол» по отношению к следующим штаммам микроорганизмов Staphylococcus aureus, Basillus subtilis, Klebsiella и Escherichia coli, а также установлено их противогрибковое действие против Candida albicans.

Ключевые слова: антибактериальная активность; суппозитории вагинальные; масло чайного дерева; метронидазол

Адреса для листування: 